\title{
Identification of two expressed flagellin genes in the insect pathogen Bacillus thuringiensis subsp. alesti
}

\author{
Ann Lövgren, ${ }^{1}$ Min-Ying Zhang, ${ }^{1}$ ÅKe Engström ${ }^{2}$ and Ritva LandÉN ${ }^{1 *}$ \\ 'Department of Microbiology, Stockholm University, S-106 91 Stockholm, Sweden \\ ${ }^{2}$ Department of Immunology, Biomedical Centre, Box 582, S-751 23 Uppsala, Sweden
}

(Received 22 June 1992; revised 7 September 1992; accepted 14 September 1992)

\begin{abstract}
Flagellin from Bacillus thuringiensis subspecies alesti strain Bt75 was isolated both from the culture medium and from flagella. Two protein forms with molecular masses close to $32 \mathrm{kDa}$ were obtained from flagella; one form was identical to the flagellin purified from the culture medium. The $\mathrm{N}$-terminal amino acid sequences were identical for both forms. Two genes coding for flagellin have been identified in $B$. thuringiensis subsp. alesti. The $f a B$ gene was cloned and sequenced in its entire length. The clone containing the $f a A$ gene was incomplete. Both genes were expressed in the mid-exponential growth phase. The $f a B$ gene was flanked by long $(355 \mathrm{bp})$ direct repeats protruding into the coding region in both the $\mathrm{N}$ - and $\mathrm{C}$-terminal parts of the gene. DNA sequences related to the $f a B$ gene were found in most other B. thuringiensis subspecies, and in two of them, subsp. kurstaki and subsp. entomocidus, such sequences were present in multiple copies.
\end{abstract}

\section{Introduction}

Bacillus thuringiensis $(\mathrm{Bt})$ is a well characterized entomophathogen found in diseased insects, in soil and in the phylloplane (Smith \& Couche, 1991). The $\delta$ endotoxin, a crystalline inclusion body produced during sporulation, is responsible for the main insecticidal activity in $\mathrm{Bt}$. The $\delta$-endotoxins have been grouped into four classes on the basis of their sequence homologies and host ranges (Höfte \& Whiteley, 1989). Different varieties of $\mathrm{Bt}$ affect different spectra of insect species. More than 20 subspecies are recognized and classified according to 14 flagellar antigens (Krieg, 1986). The correlation, if any, between $\delta$-endotoxin type and flagellar serotype is unclear. Commercial insecticidal preparations, consisting of a mixture of spores and crystals have been used worldwide during the last three decades. Lately, there have been reports of the appearance of insect populations resistant to $\mathrm{Bt}$ preparations (McGaughey, 1985; Van Rie et al., 1990; Ferre et al., 1991).

If $\mathrm{Bt}$ preparations were designed to work on different levels or with different mechanisms the risk for resistant insect populations to appear would be lessened. There

\footnotetext{
* Author for correspondence. Tel. 8-16 41 58; fax 8-612 9552.
}

The nucleotide sequence data reported in this paper have been submitted to the EMBL Data Library and has been assigned the accession numbers X67138 for flaA and X67139 for flaB. have been reports showing that the presence of small amounts of spores in insecticidal crystal preparations increase the toxicity against certain insect species ( $\mathrm{Li}$ et al., 1987; Karamanlidou et al., 1991). These findings indicate an involvement of the live organism and investigations of factors influencing host-pathogen interactions are clearly warranted. Bt produces a number of secreted substances which are toxic to insects. These include the $\beta$-exotoxin which is an ATP analogue (Sebesta \& Horska, 1970), several phospholipases (Henner et al., 1988) and the neutral metalloprotease immune inhibitor A (InA) (Sidén et al., 1979; Dalhammar \& Steiner, 1984; Lövgren et al., 1990). The Bt subsp. alesti strain Bt75 that was used for purification of InA is virulent if injected, although it lacks both the $\delta$ endotoxin and $\beta$-exotoxin (Lövgren et al., 1990). In this paper we show that Bt75 is also pathogenic if fed orally to Trichoplusia ni larvae. As InA seems to be harmless if fed to larvae (B. Lambert, unpublished results), we decided to look for factors important during the early stages of infection. Avirulent mutants in Bt subsp. gelechiae show that virulence is co-ordinately regulated with at least the expression of flagella and lecithinase (Heierson et al., 1986; A. Lövgren unpublished results), both considered virulence factors in several bacterial species (Faust, 1977; Richardson, 1991). Strain Bt75 is lecithinase negative (this paper) but is motile. Flagella are recognized as virulence factors due to involvement in motility (Richardson, 1991) and initial adhesion 
Table 1. B. thuringiensis strains used

\begin{tabular}{|c|c|c|c|c|c|}
\hline \multirow[b]{2}{*}{ Subspecies } & \multirow[b]{2}{*}{ Serotype } & \multirow[b]{2}{*}{ Strain } & \multirow[b]{2}{*}{ Source/reference } & \multicolumn{2}{|c|}{ Flagellin signal } \\
\hline & & & & $\begin{array}{l}\text { Southern } \\
\text { blot }\end{array}$ & $\begin{array}{l}\text { Western } \\
\text { blot }\end{array}$ \\
\hline alesti & $3 a$ & Bt5 & Somerville \& Pockett (1975) & + & + \\
\hline alesti & $3 \mathrm{a}$ & $\mathrm{Bt} 75^{*}$ & Edlund et al. (1976) & + & + \\
\hline gelechiae & 1 & Bt13 & Landén et al. (1981) & + & + \\
\hline kurstaki & $3 a, b$ & Bt2 & Biotrol X K (Landén et al., 1981) & Strong & - \\
\hline galleriae & $5 \mathrm{a}, \mathrm{b}$ & $\mathrm{Bt} 3$ & Entobacterin (Landén et al., 1981) & + & - \\
\hline thuringiensis & 1 & Bt4 & E61 (Landén et al., 1981) & + & + \\
\hline finitimus & 2 & $\mathrm{Bt} 8$ & Somerville \& Pockett (1975) & + & + \\
\hline aizawai & 7 & HD131 & $\begin{array}{l}\text { H. T. Dulmage, USDA, } \\
\text { Brownsville, TX, USA }\end{array}$ & + & + \\
\hline israelensis & 14 & Btal & $\begin{array}{l}\text { H. de Barjac, Institut Pasteur, } \\
\text { Paris, France }\end{array}$ & + & - \\
\hline ostrinae & $8 \mathrm{a}, \mathrm{c}$ & Bta3 & Ren et al. (1975) & + & - \\
\hline thompsoni & 12 & Bta40 & Thorne (1978) & - & - \\
\hline entomocidus & 6 & NRRL HD-9 & & Strong & - \\
\hline subtoxicus & 6 & NRRL HD-109 & & $\mathrm{ND}$ & + \\
\hline toumanoffi & $11 \mathrm{a}, \mathrm{b}$ & NRRL HDD-201 & & ND & + \\
\hline pakistani & 13 & NRRL HD-395 & (Krieg 1986) A / S, DCIIIIAI A & ND & + \\
\hline colmeri & 21 & NRRL HD-847 & & ND & + \\
\hline tohokuensis & 17 & NRRL HD-866 & & + & Weak \\
\hline tochigiensis & 19 & NRRL HD-868 & & ND & + \\
\hline
\end{tabular}

* Bt75 is derived from Bt5.

ND, Not done.

(McSweegan \& Walker, 1986). We thus decided to characterize flagella and flagellin genes to be able to investigate if flagella contribute to the invasiveness of Bt75.

This paper concerns the purification of flagellin protein and the cloning and sequencing of one complete flagellin gene and part of a second. Two remarkable features were found. First, there are long direct repeats flanking and intruding into the complete flagellin gene; second, two $\mathrm{Bt}$ subspecies contain multiple copies of at least part of the flagellin gene.

\section{Methods}

Strains and media. All B. thuringiensis strains used are listed in Table 1. Other Bacillus strains are listed in Table 2. All strains are grown in LB or TYB [12 g Bacto-tryptone $\mathrm{l}^{-1}, 6 \mathrm{~g}$ Bacto-yeast extract $\mathrm{l}^{-1}, 5 \mathrm{~g}$

Table 2. Bacillus strains used

\begin{tabular}{|c|c|c|}
\hline Strain & Bacillus species & Source/reference \\
\hline $\mathrm{Bc} 11$ & cereus & $\mathrm{Str}^{\mathrm{R}}$ from Bcl, ATCC 7389693 \\
\hline Bsp & sphaericus & Grant St Julian Agricultural \\
\hline Bpop & popilliae $\int$ & Research Service, Peora, IL, USA \\
\hline $\mathrm{Bm} 11$ & megaterium & Rasmuson \& Boman (1977) \\
\hline $260 \mathrm{I}$ & larvae & $\begin{array}{l}\text { Ingemar Fries, University of } \\
\text { Agriculture, Uppsala, Sweden }\end{array}$ \\
\hline Bcoa & coagulans & Blanka Rutberg, University of Lund, \\
\hline Bbre & brevis & Lund, Sweden \\
\hline Bste & stearothermophilus & ATCC 7953 \\
\hline
\end{tabular}

$\mathrm{NaCl}$ (of pure quality) $\mathrm{l}^{-1}, 1 \mathrm{~mm}-\mathrm{MgSO}_{4}$ and $\left.1 \mathrm{~mm}-\mathrm{CaCl}_{2}, \mathrm{pH} 7 \cdot 0\right]$ at $37^{\circ} \mathrm{C}$.

Plates used for testing lecithinase production contained $0.5 \% \mathrm{NaCl}$. $0.5 \%$ Tryptose, $2 \%(\mathrm{w} / \mathrm{v})$ agar and $0.1 \%$ phosphatidylcholine (from egg yolk), $\mathrm{pH} 7 \cdot 0$. Swarm plates for motility testing were prepared according to Ordal et al. (1983) and incubated in plastic bags for $1 \mathrm{~d}$ at $37^{\circ} \mathrm{C}$ and for $4-5 \mathrm{~d}$ at room temperature. Motility was measured as the diameter of the colony.

Rearing of T. ni larvae and feeding assay. Larvae were reared on an artificial diet as described by Shorey \& Hale (1965). For the feeding assay, larvae were fed a mixture of their normal diet of Pinto beans and selected Bt strains. Food was mixed with $7 \mathrm{ml}$ of an overnight culture of the bacteria grown in LB, to a total of $50 \mathrm{ml}$. Medical measuring cups with lids were filled with $10 \mathrm{ml}$ of this mixture; ten larvae were fed in each cup.

Purification of soluble flagellin and flagella. For purification of soluble flagellin, strain Bt 75 cultures were grown overnight at $37^{\circ} \mathrm{C}$ in TYB supplemented with $1.5 \%(\mathrm{w} / \mathrm{v})$ glucose. The soluble flagellin was first purified as a cross-reacting protein on an antibody column as described by Lövgren et al. (1990). This material was used to raise antiserum in rabbits by standard procedures using Freund's complete adjuvant, and for amino acid sequencing of the $\mathrm{N}$-terminus of the soluble flagellin.

The antiserum raised against soluble flagellin was purified by ammonium sulphate precipitation at $45 \%$ saturation and coupled to CNBr-activated Sepharose 4B (Pharmacia) by the procedure recommended by the manufacturer. Sample application and washing of the column was done as described by Lövgren et al. (1990). The column was eluted with $1 \mathrm{M}$-propionic acid and the fractions collected were lyophilized immediately. The recovery was approximately $1 \mathrm{mg}$ of soluble flagellin per litre of culture.

For purification of flagella Bt75 was grown to about 120 Klett in LB. Bacteria were washed once in $10 \mathrm{~mm}$-Tris/ $\mathrm{HCl}, \mathrm{pH} 7.5$, and resuspended in the same buffer. The cells were shaken vigorously for 
$10 \mathrm{~min}$ to shear off the flagella. Whole bacteria were removed by centrifugation twice at $10000 \mathrm{~g}$ for $15 \mathrm{~min}$. Flagella were then pelleted at $100000 \mathrm{~g}$ for $1 \mathrm{~h}$ and resuspended in $50 \mathrm{~mm}$-ammonium hydrogen carbonate buffer. The recovery was about $2 \mathrm{mg}$ of flagella per litre of culture.

Amino acid sequencing. The soluble flagellin was used directly for Nterminal amino acid sequence determination by the method of Edman \& Begg (1967).

Flagellin derived from flagella was first run in SDS-PAGE and then electroblotted onto an Immobilon $\mathrm{P}$ membrane (Millipore) by the procedures described by Goding (1983). The membrane was stained with Coomassie Brilliant Blue, and the flagellin band was cut out and used for amino acid sequence analyses by the same method as above.

Analysis of flagellin content by ELISA. Dynatech 129 B plates were coated overnight at $4{ }^{\circ} \mathrm{C}$ with sterile filtered Bt5 culture samples. The plates were washed three times for $10 \mathrm{~min}$ with $0.9 \% \mathrm{NaCl}$ and $0.05 \%$ Tween 20 (EIA purity, Bio-Rad). Flagellin antibodies diluted in Trisbuffered saline (TBS, $10 \mathrm{~mm}$-Tris $/ \mathrm{HCl}, \mathrm{pH} 8.0,150 \mathrm{~mm}-\mathrm{NaCl}$ ) containing $1 \%(\mathrm{w} / \mathrm{v})$ BSA were added to the plates, which were then incubated at room temperature for $2 \mathrm{~h}$ or alternatively at $4{ }^{\circ} \mathrm{C}$ overnight. After washing as above, an anti-rabbit alkaline phosphatase conjugate (Sigma A-7778), diluted in TBS containing $1 \%$ BSA, was added and plates were incubated at room temperature for $2 \mathrm{~h}$. Plates were washed four times and the substrate solution, $p$-nitrophenyl phosphate, prepared according to the manufacturer's (Sigma) instructions, was added. Plates were read after $15-20 \mathrm{~min}$ in an ELISA photometer.

Cloning of the flagellin genes. Libraries of Bt5 DNA were constructed as described by Lövgren et al. (1990), and screened with a mixed oligonucleotide probe constructed from the N-terminal amino acid sequence of the purified flagellin. The probe, synthesized by Symbicon (Umeå, Sweden), contained inosine (I), and had the following sequence 5'CATTTTATCTTGGTTTTGGCICATGTATTCTTG $(\mathrm{C} / \mathrm{T})$ GTGCICAT3'.

DNA methods. DNA from different Bt subspecies was extracted essentially as described by Lövgren et al. (1990).

Oligonucleotide probes were end-labelled using T4 polynucleotide kinase according to Maniatis et al. (1982), and probes derived from cloned sequences were labelled with the Amersham multi-prime labelling kit according to the manufacturer's instructions. Double- and single-stranded DNA sequencing was performed with the Sequenase kit (United States Biochemicals) using subclones and deletion clones as indicated (see Fig. 2).

In Southern blots, Hybond $\mathrm{N}$ membranes (Amersham) were used according to the manufacturer's instructions. Hybridizations were done at $55^{\circ} \mathrm{C}$, using either the cloned sequences or the 42 -mer oligonucleotide as probe.

All other DNA work was done according to standard methods (Maniatis et al., 1982).

Sequence homologies were searched for in the NBRF protein resource and the EMBL/GeneBank/DDBJ Nucleotide Sequence Data Libraries using the University of Wisconsin Genetics Computer Group program (George et al., 1986).

Preparation of RNA from Bt. Bacteria were cultivated to the mid- or late-exponential growth phase $(150 \mathrm{Klett})$ in $30 \mathrm{ml}$ of TYB and harvested by centrifugation at $2000 \mathrm{~g}$. The cells were then washed and resuspended in $5 \mathrm{ml}$ of lysis buffer $(30 \mathrm{~mm}-\mathrm{Tris} / \mathrm{HCl}, 100 \mathrm{~mm}-\mathrm{NaCl}$ and 5 mM-EDTA, pH 8.0) to which $40-50 \mathrm{U}$ of mutanolysin $\mathrm{ml}^{-1}$ and $1 \mathrm{mg}$ of lysozyme $\mathrm{ml}^{-1}$ were added. Tubes were placed on ice and shaken for $1.5 \mathrm{~h}$. SDS was added to a final concentration of $0.5 \%$ and the mixture was then incubated for $40 \mathrm{~min}$ at $65^{\circ} \mathrm{C}$. This step was followed by extraction with hot phenol $\left(65^{\circ} \mathrm{C}\right)$ three to four times, and chloroform/isoamyl alcohol $(24: 1, \mathrm{v} / \mathrm{v})$ twice. The RNA was recovered by precipitation with $2.5 \mathrm{vols}$ ethanol in the presence of $0.1 \mathrm{vol}$ $3 \mathrm{M}$-sodium acetate, $\mathrm{pH} 4.8$, at $-70{ }^{\circ} \mathrm{C}$ for $20 \mathrm{~min}$ followed by centrifugation at $10000 \mathrm{~g}$ for $10 \mathrm{~min}$ to pellet the nucleic acids.

Northern blots. RNA isolated from Bt5 was separated on a $1.5 \%$ (w/v) agarose gel according to Klemenz et al. (1985) and blotted onto Hybond $\mathrm{N}$ membranes (Amersham) by the capillary blot method. Membranes were hybridized at $42{ }^{\circ} \mathrm{C}$ for $45 \mathrm{~h}$ with end-labelled oligonucleotide probes in a buffer of $5 \times$ Denhardt's solution, $5 \times$ SSC and $0.5 \%$ SDS, at both high $(58 \%, \mathrm{v} / \mathrm{v}$, formamide) and low $(43 \%$ formamide) stringency conditions. Following hybridization the membranes were washed twice at room temperature for $5 \mathrm{~min}$ and once at $55^{\circ} \mathrm{C}$ for $10 \mathrm{~min}$ in $2 \times \mathrm{SSC}$ containing $0.1 \% \mathrm{SDS}$ and, finally once at $60^{\circ} \mathrm{C}$ for $20 \mathrm{~min}$ in $0.2 \times \mathrm{SSC}$ containing $0.1 \% \mathrm{SDS}$.

The sequences of the oligonucleotide probes used in the Northern blots were determined from the DNA sequence (see Fig. 3) and synthesized using a Gene Assembler (Pharmacia).

Slot-blot of DNA. For the slot-blot experiment, DNA samples $(0 \cdot 1-40 \mu \mathrm{g})$ in a volume of $100 \mu \mathrm{l}$ were mixed with $300 \mu \mathrm{l}$ of a formaldehyde $/ 20 \times \operatorname{SSC}(1: 2, \mathrm{v} / \mathrm{v})$ mixture. The samples were incubated for $15 \mathrm{~min}$ at $70^{\circ} \mathrm{C}$ and applied to Hybond $\mathrm{N}$ membranes in a slot-blot device. Hybridization of the membrane was done according to the manufacturer's instructions, except that the temperature was $48^{\circ} \mathrm{C}$ and the last high stringency wash was omitted. In this experiment. the 42-mer oligonucleotide was used as probe. The autoradiogram was scanned with a hand scanner and quantified with the Scan Analysis program (Biosoft, Cambridge, UK)

\section{Results}

Feeding of the $\delta$-endotoxin- and $\beta$-exotoxin-negative mutant Bt75 to T. ni larvae

The presence of small amounts of spores in insecticidal crystal preparations increases the toxicity against certain insect species, but addition of antibiotics to the insect diet abolishes the effect of the spores (Li et al., 1987; Karamanlidou et al., 1991). One may therefore speculate that the spores germinate and that the resulting vegetative bacteria contribute to the lethality of the mixtures. To test if the $\delta$-endotoxin-negative mutant $\mathrm{Bt} 75$ is able to kill T. ni larvae by feeding, an overnight culture of the mutant was mixed with the larval diet $(15 \%, v / v$, corresponding to an initial diet concentration of about $2 \times 10^{7}$ bacteria per $\mathrm{ml}$ of diet). Table 3 shows that all larvae were killed by the wild-type alest $i$ strain $\mathrm{Bt} 5$ and

\section{Table 3. Feeding of T. ni larvae with Bt subsp. alesti and subsp. gelechiae}

The figures are results from three separate experiments. ND, Not determined.

\begin{tabular}{lccc}
\hline \hline $\begin{array}{l}\text { Strain } \\
\text { added }\end{array}$ & $\begin{array}{c}\text { Dead larvae/ } \\
\text { total larvae }\end{array}$ & $\begin{array}{c}\text { Mortality } \\
(\%)\end{array}$ & $\begin{array}{c}\text { Average weight } \\
\text { of surviving larvae }\end{array}$ \\
\hline Bt5 & $35 / 35$ & 100 & \\
Bt75 & $17 / 36$ & 48 & 34 \\
Bt1302* & $12 / 50$ & 24 & ND \\
None & $3 / 35$ & 8 & 105 \\
\hline
\end{tabular}

* Strain Bt1302 is an aflagellated, avirulent, acrystalliferous derivative of $\mathrm{Bt} 13$ (Heierson et al., 1986). 


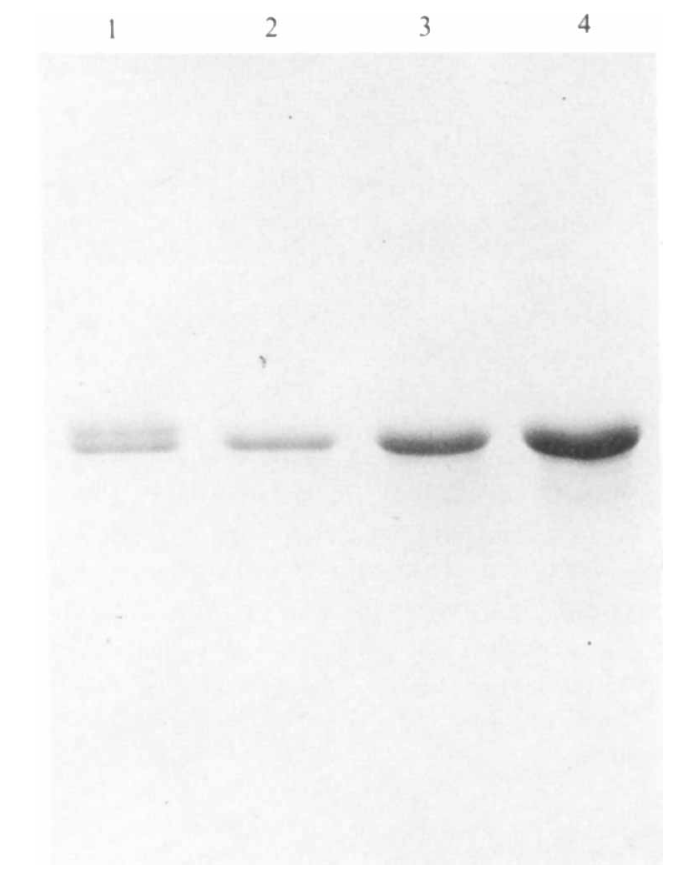

Fig. 1. SDS-PAGE of immunosorbent purified $\mathrm{Bt} 75$ soluble flagellin stained with Coomassie Brilliant Blue. Lanes 2-4, samples $(5 \mu \mathrm{l})$ of different fractions eluted from the same purification: lane 1, Bt75 flagellin $(1 \mu \mathrm{g})$ derived from flagella by the procedure described in Methods.

(a)

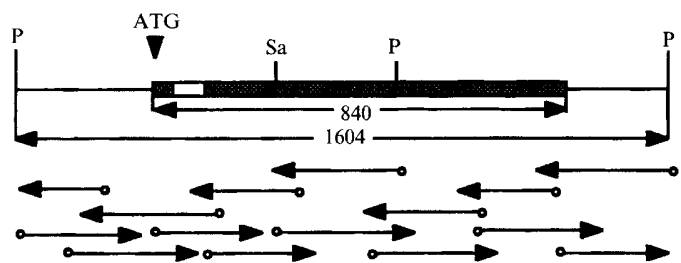

(b) $\mathrm{pT} 33-1$

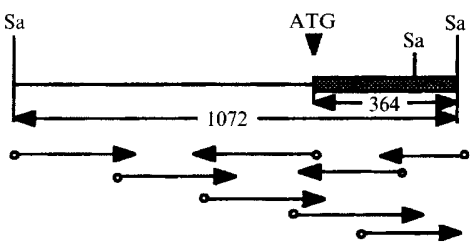

Fig. 2. Restriction map and DNA sequencing strategies of Bt5 flagellin genes. The sequencing strategies on both strands of both clones, pT33-1 and pT33-2, are shown by arrows. The coding regions are shown by shaded boxes. The position of the sequence corresponding to the oligonucleotide used in the primary screening is indicated as an open box. Restriction enzyme sites are designated as follows: P, Pst I Sa, Sau3a.

that almost $50 \%$ of the larvae were killed by the mutant strain Bt75. The surviving larvae fed with $\mathrm{Bt} 75$ were much smaller, weighing an average of $34 \mathrm{mg}$ as compared to the control larvae fed with uncontaminated food, weighing an average of $105 \mathrm{mg}$. This suggests that some component other than the $\delta$-endotoxin aids in the establishment of a Bt infection.

\section{Characterization of $B t 75$}

The strain is a protease-deficient strain originally selected to facilitate the purification of InA (Sidén et al., 1979). To further characterize this mutant we investigated its motility and lecithinase expression. We found that Bt75 is motile but does not secrete lecithinase (results not shown). Strain Bt75 is thus $\delta$-endotoxin-, $\beta$-exotoxinand lecithinase-negative, expresses low amounts of proteases but remains motile.

\section{Purification of flagellin and determination of the $\mathrm{N}$-terminal amino acid sequence}

We isolated the Bt75 flagellin in two different ways. The first method was to isolate and then heat flagella in the presence of DTT and SDS to depolymerize the flagella and thus releasing flagella-derived flagellin. Using the second method, soluble flagellin was isolated from culture medium taking advantage of the ability of antiInA serum to react with alesti flagellin (Lövgren et al., 1990). In addition, a recently developed specific antiflagellin serum (raised against monomeric flagellin purified from culture filtrate) was used for purification of soluble flagellin. An antiserum directed against whole flagella, purified as described in Methods, was also raised; this antiserum reacts with both flagella-derived flagellin and soluble flagellin, and with native flagella in dot-blots and in Western blot experiments; however, it did not prove useful for purification of the soluble flagellin. SDS-PAGE analysis of affinity-purified flagellin from sterile filtered culture medium gives rise to a single band of molecular mass estimated at $32 \mathrm{kDa}$ (Fig. 1, lanes 2-4). Flagella-derived flagellin gives rise to an additional band of a slightly higher molecular mass (Fig. 1, lane 1). The $\mathrm{N}$-terminal amino acid sequences of both soluble flagellin and flagella-derived flagellin were determined and found to be identical (Fig. 3).

\section{Biological activity of Bt75 flagellin}

Soluble Bt75 flagellin and depolymerized Bt75 flagella were separately injected into $T . n i$ by the procedure described by Lövgren et al. (1990). The $\mathrm{LD}_{50}$ dose as determined by the endpoint titration method is approximately $50 \mathrm{ng}$ per $\mathrm{mg}$ larval body weight, which is comparable to the $\mathrm{LD}_{50}$ doses we have estimated for proteases such as trypsin and chymotrypsin. Injections of $500 \mathrm{ng}$ per mg larval body weight of chicken lysozyme or bovine serum albumin did not give any observable effects.

\section{Cloning and sequencing of the flagellin genes}

The N-terminal amino acid sequence was used to design a 42-mer oligonucleotide which was used as a probe to 
1 CTGCAGCAGCTCAAATCACGGCTCTTGACACTGC PT33.2

1 ACTCATATCTTCTATTTTTGCCGGCAGCGTAGTAGCCTTCGTCTCCCTCGCAGGTTCACTCTGCAACTTCTCTTGAAAACGACTACTMACANATGCTTGTGACTACT PT33-1 35 TATTCAAGAAATTECTGACGCTAGAGCAACTTTCGGTTCTCAATTAMACCGTTAGACCATAACTTMACAACGTMACGAGCCAAGCTACTMATATGGCAGCTTCTG 108 TAGCTTITGCTGAATTTGTCCTITTTTATATGCAACACTTCTTT TACTATATTTCCMCTMACATAATATCACCTTTTCGGTAACAAGATMATCTAATATTAGA Rep 1

142 CTTCTCAAATTGAAGATGCTGATATGGCAAMAGAMTGTCTMCATGACAMAGTTCAMATTTTMACGAAGCAGGCATCAGCATGCTTTCTCAAGCTAMCCAAACT 215 GTTTTTTTTT TAAGTTTGCAATAATCCTTTTGATATATTGTAATAAAAMATGACAMTAGGMATTATCATTTTTTTATATTCATTAATTACAATTATTCGTTG $=35 \quad-10 \quad-35$

249 CCACAATGGTTTCTAATTATTACMATMATCCATTTGACATATACTCTCTGTAGTATATMMAGATITTCTTTTMATMATTMAAATTMATGGGGGTTCTTAAC 322 ACACGATATACACCAAGGATIACAATTAATCTCGMATTGATTTTTTTGCATATTIACGTITMACAATTMACAGAMAMTCAATATAMAMAMTGGGGGT TCTTAAC $\overline{7^{35}}-1-10$

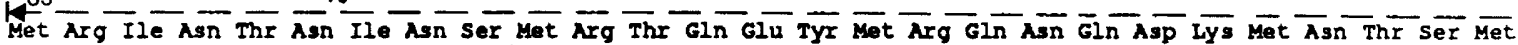
356 ATG AGA ATT AAT ACA AAC ATT MAC AGC ATG CGT ACT CMA GAG TAC ATG CGA CMA MAC CAA GAC AMA ATG AAT ACA TCT ATG $T$ C T

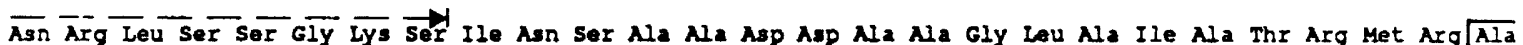
438 AAC CGT TTA TCT AGC GGT AAX TCA ATT MAC AGT GCA GCT GAC GAT GCG GCT GGC TTA GCT ATT GCT ACT CGT ATG CGT GCG C $\mathbf{T}$

Lys Glu Giy Gly Lou Asn Val Gly Ala Arg Aen Thr Gin Aap Ala yet ser Ala Leu Arg Thr Gly Asp Ala Ala Leu Gly 519 MA GA GGC GGA TTA MA GTT GGA GCA CGT MAC ACA CM GAC GCT ATG TCT GCT TTA CGT ACT GGT GAC GCT GCA TTA GGT $\mathbf{T}$ $\mathbf{G} \mathbf{T}$

Ser Val Ser Asn Ile Leu Leu Arg Met Arg Asp Leu Ala Thr Gin Ala Ser Ser Gly Thr Asn Asn Asp Lys Asp Ile Ala 600 TCT GTT TCA MAC ATC TSA CTT CGT ATG CGT GAT CTT GCA ACA CAA GCA TCA AGC GGT ACT MAC MA GAT MAA GAT ATC GCA

Ser Met Asp Lys Glu Tyr Gln Ala Leu Ala Gln Glu Ile Asn His Ile Ala Asp Lys Thr Asn Phe Asn Gly Asn Ala Phe 681 TCT ATG GAC MAA GAG TAT CMA GCA TTA GCA CAA GA ATT MT CAT ATT GCT GAT MA ACA MAT TTC AAT GGT AAC GCA TTT G K- End of pr33-1

Lel Asn Lys Gly Thr Asn pro Asp Glu Gly lys Asp Ile Thr Ile Gln Leu ser Asp Ala ser ser Asp Thr Met Ile Ile 762 TTA MAT MA GGT ACT MAT CCT GAT GAG GGT MA GAT ATC ACG ATT CAA CTT TCT GAT GCT TCA AGT GAT ACA ATG ATA ATC

Ala Ala Ile Glu Thr Lys Lys Leu Thr Thr Ala Thr Lou Na Val ser Thr Asp Gly Thr Lys Lys Leu Asp Ala Thr Thr 843 GCA GCT ATC GAA ACA MA NAA TTA ACA ACT GCT ACT TTA GCA GTT TCA ACT GAT GGA ACA MAG MA TTA GAT GCT ACA ACT

Ala Ala Thr Glu Ile Thr Ala Lou Asp Thr Ala Ile Gln Aen Ile Ala Asp Ala Arg Ala thr Phe Gly Ser Gin Leu Ash 924 GCA GCA ACT GAA ATC ACG GCT CTG GAC ACT GCT ATT CAG MAT ATC FCT GAC GCT MGA GCA ACT TTC GGT TCT CAA ITA AAC Rep2

Arg Leu Asp his Asn Leu Asn Asn Val Thr Ser Gin Ala Thr Asn bet Ma Ala Ser Ala Ser Gin Ile Glu Asp Ala Asp 1005 CGT TTA GAC CAT MAC TTA MAC MC GTA ACG AGC CA GCT ACT AAT ATG GCA GCT TCT GCT TCT CAA ATT GAA GAT GCT GAT

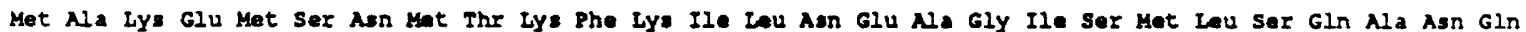
1086 ATG GCA AMA GA ATG TCT MC ATG ACA MG TTC AM ATT TTA MA GA GCA GGC ATC AGC ATG CTT TCT CAA GCT MA CAA

Thr Pro Gln Met Val Ser Ly: Leu Leu Gln stop

1167 ACT CCA CAA ATG GTT TCT MA TTA TTA CM TM TCCATTTGAMCATATACTCTCTGTAGTATATAMGAGTTTTCTTTTAMTAATTAMA TIA

1263 TGGGGTTCTTAMCATGAGATTMATACMMCATTACACCATGCGTACTCAAGAGTACATMAGGTCATTATATTATAGACGTCTACMAGGTTTATTTTTATCG

1370 gtTGATAGACGTATATATGACGTTTTCTCAGTGTCTACAMATGTGTACCTTTTTAGACTGCTATCCACGGGAGCATAGTATATCAMATAGGGCGACCATATACC

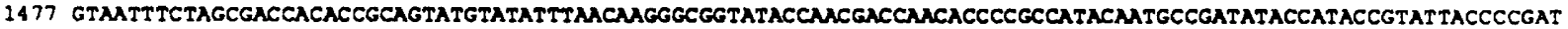

1584 ATMACAAGCccoccatatgtTa

Fig. 3. DNA sequences of the Bt5 flagellin genes and the derived amino acid sequences. The sequence of the complete clone containing the $f a B$ gene, pT33-2 (top), and the incomplete clone containing the 5' part of $f a A$, pT33-1 (bottom), are aligned without gaps to create maximum fit in the coding region. In the coding part, the derived amino acid sequence is shown above the nucleotide sequence of pT33-2. Only the few nucleotide sequence differences in pT33-1 compared to pT33-2 are indicated in this area. One of these changes results in a change of an amino acid residue, namely the change in the last codon in the sequence of pT33-1. The N-terminal amino acid sequence, determined from the purified proteins, is marked with a broken line above the sequence. The part used for constructing the flagellin gene probe is boxed in. Another box containing nucleotide sequences indicates the position of the gene-specific oligonucleotides. In pT33-1, promoter recognition sites for a putative flagellin gene are indicated at the -24 to -12 position (starting at nt 23) and -35 and -10 (starting at nt 319). Similarly, in the pT33-2 clone, putative classical vegetative promoters are indicated as -35 and -10 (starting at nt 248 and nt 284 respectively). The underlined sequences in pT33-2 constitute a 355 -bp-long direct repeat and the two sequences are marked Rep1 and Rep2, respectively. 


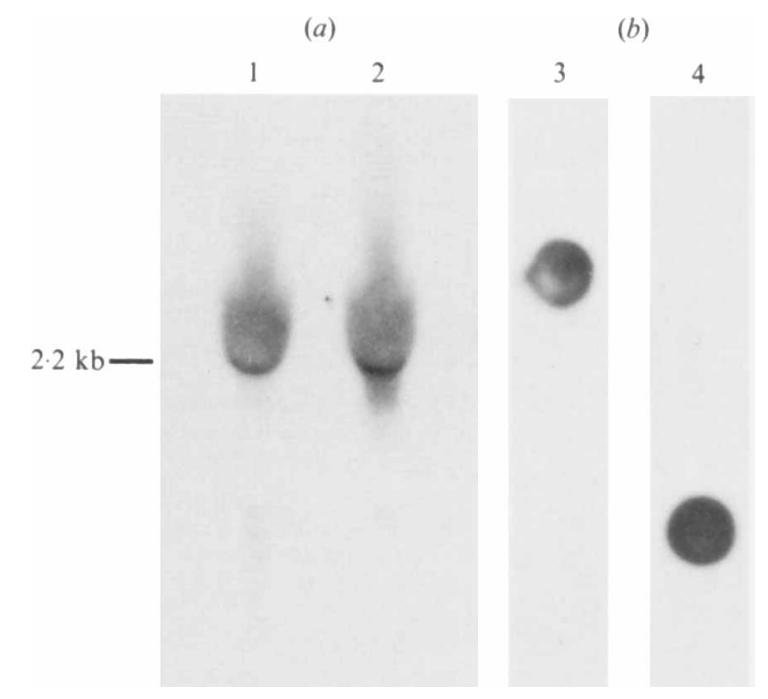

Fig. 4. (a) Northern blot of Bt5 total RNA. RNA in lane 1 was probed with the $f l a A$-specific oligonucleotide and lane 2 was probed with the flaB-specific oligonucleotide. The same amount of RNA $(80 \mu \mathrm{g})$ was loaded in each lane. This Northern blot was hybridized at the high stringency conditions described in Methods. (b) Strips from a dot-blot included in the hybridization experiments, where the upper dot is from clone pT33-1 containing the flaA gene, and the lower dot is from clone pT33-2 containing the $f a B$ gene. Lane 3 shows the strip hybridized with the $f a A$-specific oligonucleotide and lane 4 shows the strip hybridized with the $f a B$-specific oligonucleotide.

screen for the flagellin gene from chromosomal DNA libraries constructed from Bt subsp. alesti strain Bt5 (Lövgren et al., 1990). The strategy for designing the primary 42-mer oligonucleotide probe was to have a fairly long probe and to avoid the complication of several variants. In the probe sequence we allowed for GT pairing and consequently followed the codon usage preferences deduced from the cloned $\delta$-endotoxin genes (Schnepf et al., 1985) and the ina gene (Lövgren et al., 1990). In the third codon position, inosine was inserted when no preferred choice was possible, resulting in only two variants of the probe (see Methods), which proved to be very efficient with only five mismatches with the actual sequence in the flagellin genes. Two of these mismatches are GT pairs and may not disturb the hybridization.

We obtained one positive clone, designated pT33-1 (Fig. $2 b$ ). One of the ORFs in the sequence, which we have named $f a A$, codes for a protein that fully matches the amino acid sequence of the $\mathrm{N}$-terminal part of the purified protein (Fig. 3). However, the length of the ORF ( $330 \mathrm{bp}$ ) is truncated by the cloning site and is thus too short to give a protein of the expected size, $32 \mathrm{kDa}$. A second screen, using the pT33-1 insert as probe, gave a clone with a 1608 bp insert, designated pT33-2 (Fig. 2a). This insert contains an ORF of $840 \mathrm{bp}$, coding for a protein of 280 amino acids; we named this new gene $\mathrm{faB}$. The nucleotide sequences and the deduced amino acid sequence of the $f a A$ and $f l a B$ genes are shown in Fig. 3. The N-terminal parts of the deduced amino acid sequences from both $f a A$ and $f a B$ are identical to the $\mathrm{N}$-terminal sequence determined by protein sequence analysis of purified flagellin. As both Southern blot experiments (results not shown) and the upstream regions of the two ORFs clearly show that there are two genes coding for flagellin in subsp. alesti, we made efforts to obtain the complete sequence of the fla $\mathrm{A}$ gene. Taking advantage of the sequence differences in the DNA sequences of the two clones, we designed two oligonucleotide probes (see Fig. 3), specific for the two genes, $f l a A$ and $f l a B$. Our efforts to clone the C-terminal part of the $f l a A$ gene continue.

\section{Sequence analysis of the flaA- and flaB-containing clones}

A comparison of the two DNA sequences reveals very few differences in the coding region and only one of the nucleotide changes results in a change of an amino acid; $A \mathrm{Ap}^{122}$ in $f l a A$ is changed to an asparagine residue in $f a B$. The other 11 differences are in the third position of the codons and do not affect the amino acid sequence. In contrast to these coding region similarities, the upstream regions differ considerably above $30 \mathrm{bp}$ upstream of the start codon. There is an alternative start codon 15 bases upstream from the one indicated in Fig. 3; however, protein data agree fully with the indicated site.

The pT33-2 clone sequence reveals two identical 355 bp direct repeats, which cover bases 49 to 403 and bases 969 to 1323 (Fig. 3). In the $f l a B$ gene, the last 47 bases in repeat number 1 (Rep 1) code for the $\mathrm{N}$-terminal part and the first 228 bases of the second repeat (Rep 2) comprise the $\mathrm{C}$-terminal part. The same reading frame is not used in the two repeats when coding for the flagellin gene. The incomplete flaA clone, pT33-1, contains only the $3^{\prime}$ end of the repeat (Rep 1) that codes for the $\mathrm{N}$ terminal flagellin sequence. Since the clone is not a fulllength one, we do not know anything about the repeat size or if there indeed is such a repeat in the fla $\mathrm{A}$ gene.

\section{Expression of flagellin genes in Bt and E. coli}

Northern blot experiments were done to determine if both genes - $f a A$ and $f a B$ - that code for flagellin in subspecies alesti are actually transcribed. RNA isolated from mid- or late-exponential phase cultures was probed with the $f a A$ - and $f a B$-specific probes, resulting in one band from each probe (Fig. 4). Since we have shown (Fig. 4) that the two probes are specific under the high stringency conditions used in the hybridization, we conclude that both $f a$ genes are transcribed in subspecies alesti.

In several bacterial species, the entire flagellar regulon is under catabolite repression (Helmann, 1991). To test if 


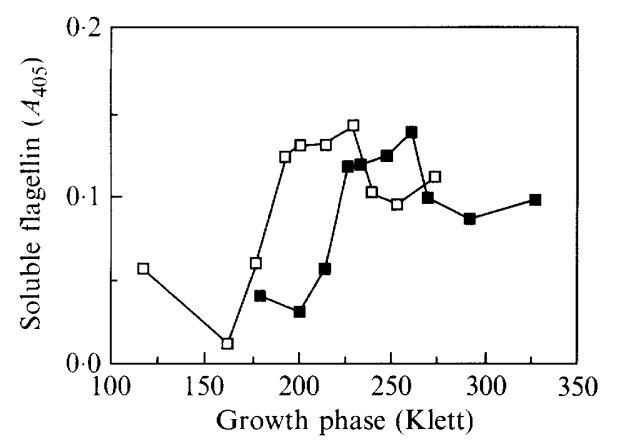

Fig. 5. Expression of flagellin determined using anti-flagellin serum in an ELISA. Bacteria were grown in TYB with ( $\square$ ) or without ( $\square$ ) glucose and the amount of soluble flagellin was measured as the absorbance at $405 \mathrm{~nm}$. The absorbance values are normalized to values of 100 Klett.

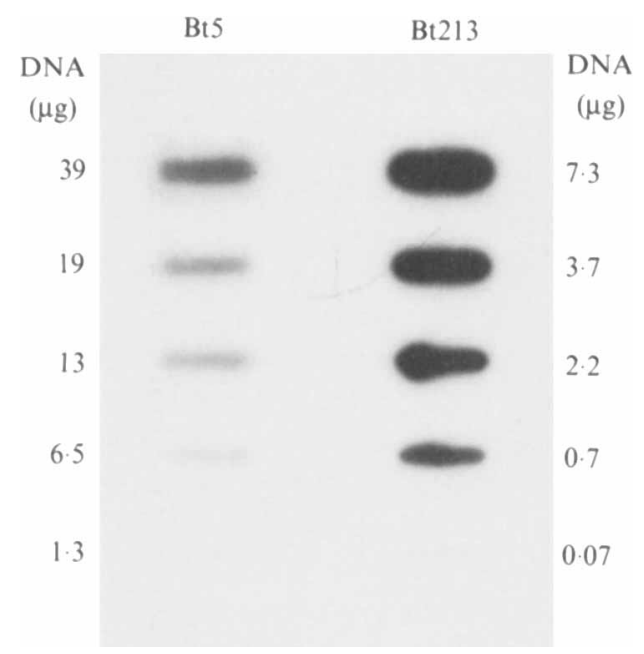

Fig. 6. Slot-blot analysis of genomic DNA from subsp. alesti (Bt5) and subsp. kurstaki ( $\mathrm{Bt213})$. The amount of DNA in each slot is indicated.

this is also the case in Bt subsp. alesti, strain Bt5 was grown with and without glucose and the expression of flagellin was monitored in an ELISA. Flagellin expression was delayed but not completely repressed in the presence of glucose (Fig. 5).

The $\mathrm{Bt}$ flagellin protein is expressed in E. coli strain DH $5 \alpha$, carrying the pT33-2 plasmid (results of Western blot experiments not shown). As indicated in Fig. 3, there is a putative conventional vegetative promoter in this clone and it seems reasonable that this promoter is used in E. coli. By introducing the plasmid carrying the Bt $f l a B$ gene into a flagellin-negative $E$. coli mutant (flaH585, CGSC 4865), we tried to complement the defect in E. coli and assayed the motility both on swarm plates and by microscopy with the following results. The motility of the flagellin-negative mutant was not restored but the originally motile controls, DH $5 \alpha$ and an E. coli wild-type strain (MG1655) showed decreased motility when harbouring the clone pT33-2, indicating that the $f l a B$ product might be incorporated in E. coli flagella or interfering with flagella assembly (results not shown). Controls, such as DH5 $\alpha$ harbouring a plasmid with an unrelated insert (pAZ3, expression clone of ina: Lövgren et al., 1990) remained fully motile.

\section{Distribution of flaB sequences among other Bt subspecies and among other bacilli}

Preparations of total undigested DNA from 13 different Bt subspecies as well as Bacillus cereus, Bacillus sphaericus, Bacillus subtilis, Bacillus megaterium. Bacillus stearothermophilus, Bacillus brevis, Bacillus larvae and Bacillus coagulans were tested in a Southern blot experiment using the complete $f a B$ clone from Bt 5 as probe. As shown in Table 1, 12 of the $13 \mathrm{Bt}$ subspecies tested gave a signal; all other Bacillus species tested were negative, with the exception of $B$. cereus, which gave a weak signal (results not shown). In Western blot experiments 12 of $18 \mathrm{Bt}$ subspecies gave a positive signal (Table 1).

Two Bt strains, belonging to subsp. kurstaki and subsp. entomocidus, gave unexpectedly strong signals compared to that of the Bt5 control sample when tested in the above Southern blot experiment. This observation was controlled using a number of subspecies in a Southern blot experiment with Pst I-digested DNA as target. Subspecies gelechiae, thuringiensis and tohokuchsis produced one distinct band, whereas subsp. alesti gave bands compatible with our cloned genes (results not shown). In contrast, hybridizing the probe to subsp. kurstaki produced two bands (results not shown), one of which is of the same size as one of the alesti bands. To estimate the copy number of the hybridizing sequence, a slot-blot experiment was done on subsp. kurstaki using the original 42-mer oligonucleotide as probe (Fig. 6). By scanning the autoradiogram, we estimated that the hybridizing sequence is close to 20 times more abundant in subsp. kurstaki than in subsp. alesti. Despite this. flagella purified from subsp. kurstaki seem to contain only one form of flagellin of the same size as the Bt75 flagellin (results not shown).

\section{Discussion}

Our feeding experiment suggests that the $\delta$-endotoxin is not an absolute requirement in Bt pathogenesis: the organism is able to colonize the host using other factors. The first step in an infection is the adherence of the bacterium to host cells, a step which could be aided by flagella. After adhesion, Bt invades the haemocel as reported by Faust (1977) and Cooper et al. (1990). However, even if a high dose of injected flagellin is harmful, the flagellin protein as such is probably not significant as a toxin in a natural environment. 
Pa MALTVNTNI ASLNTQRNLNNSSASINTSLQRLSTGSRINSAKDDAAGLQIANRLTSQVNGLNVAT KNANDGIS LAQTAEGAL

BS MRINHNI AALNTLNRLSSNNSASQKNMEKLSSGIRINRAGDDAAGLAISEKMRGQIRGLEMASKNSQDGISLIQTAEGAL

EC MAQVINTNSLSLITQNNINKNQSALSSSIERLSSGLRINSAKDDAAGQAIANRFTSNIKGLTQAARNANDGISVAQT $I G A L$

Bt MRINTNINSMRTQEYMRQNQDKMNTSMNRLSSGKSINSAADDAAGLAIATRMRAKEGGLNVGARNTQDAMSALRTGDAAL

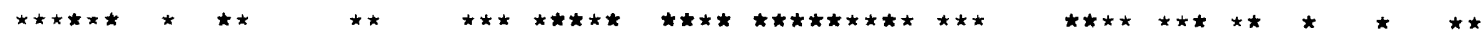

Pa QQSTNILQRMRDISLQSAN-G-SNSDSERTALNGEAKQLQKELDRISNTTTFGGRKLIDGS-_-

BS TETHAILQRVRELVVQAGNTGTQDKATDLQS IQDEISALTDEIDGISNRTEFNGKKLLDGT -

EC SEINNNLQRVRELTVQATT-G-TNSESDLSSIQDEIKSRLDEIDRVSGQTQFNGVNVLAKN-_-

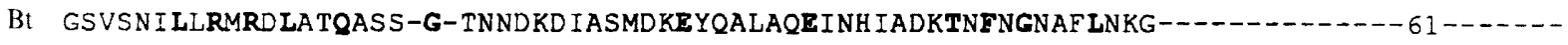

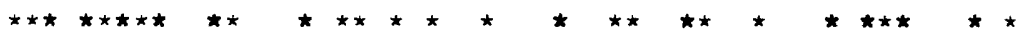

\begin{abstract}
Pa IKQIDASVPTSVAVQNRFDNTINNLKNIGENVSAARGRIEDTDFAAETANLTRNQVLQQAGTAILAQANQLPQSVLSLLR
BS INQVSSQRAKLGAVQNRLEHTINNLSASGENLTAAESRIRDVDMAKIMSEFTRNNI LSQASQAMLAQANQQPQNVLQLIR

EC IASVDKFRSSLGAVQNRLDSAVTNLNNTTTNLSEAQSRIQDADYATEVSNMSRAQI IQQAGNSVLAKANQVPQQVLSLLQG

Bt IQN IADARATFGSQLNRLDHNLNNVTSQATNMAASASQIEDADMAKEMSNMTKFKI LNEAGISMLSQANQTPQMVSKLLQ

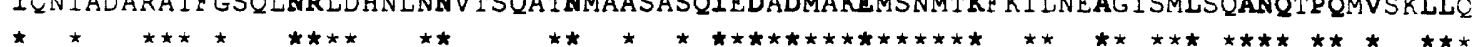

Fig. 7. Comparison of the Bt subsp. alesti flagellin amino acid sequence with the $\mathrm{N}$-terminal and C-terminal amino acid sequences of flagellins from P. aeruginosa (Pa; Totten \& Lory, 1990), B. subtilis (Bs; Mirel \& Chamberline, 1989) and E. coli (Ec; Kuwajima et al., 1986). Only the first 139 and the last 80 amino acid residues are shown. The numbers between the $\mathrm{N}$-terminal and $\mathrm{C}$-terminal sequences denote the number of amino acid residues in the variable part. Amino acid residues identical in all four sequences are shown in bold type. An asterisk $\left(^{*}\right)$ under an amino acid residue in the $\mathrm{Bt}$ flagellin indicates that an identical amino acid residue is found in at least one other flagellin protein at this position.

We have identified two flagellin genes, $f a A$ and $f a B$, in Bt5 subsp. alesti and have cloned the complete coding sequence of $f a B$ and the N-terminal half of the $f a A$ coding sequence. The $5^{\prime}$ coding sequences of these two genes are very similar; there are only a few nucleotide differences resulting in one amino acid change. The start site indicated in Fig. 3 fully agrees with our protein data for both Bt flagellins, and with the N-terminal amino acid sequence of Bacillus subtilis flagellin (see Fig. 7). However, processing of flagellin protein cannot be excluded since there is an alternative start site $15 \mathrm{bp}$ upstream of the one we have indicated (Fig. 3). Amino acid differences in the C-terminal part of the flagellin proteins (yet unsequenced in $f(a A$ ) or post-translational modifications of one of the flagellin proteins might explain the double band seen from purified Bt75 flagella run in SDS-PAGE (Fig. 1). Examples of possible modifications are phosphorylation of tyrosine residues (Kelly-Wintenberg et al., 1990) and modification of serine residues (Logan et al., 1989). Regardless of the reason for the two flagellin forms, both are incorporated into Bt subsp. alesti flagella (Fig. 1, lane 1). The two flagellin genes are expressed simultaneously, as RNA data show (Fig. 4), and the different protein forms present in flagella may represent the protein products from these genes, but this remains to be examined. In Bacillus pumilus, the presence of two flagellins in the flagella has been demonstrated (Oiler et al., 1971). The presence of two flagellin genes is also well established in micro-organisms such as Salmonella, Campylobacter, Helicobacter and Rhizobium (Szekely \& Simon, 1983;
Guerry et al., 1991; Kostrzynska et al., 1991; Bergman et $a l ., 1991)$, but these species are more distantly related to Bt than B.pumilus. In the Salmonella example, the two genes are used for differential expression; in the Campylobacter and Helicobacter case, the two protein products are incorporated in different parts of the flagella; in Rhizobium, the two flagellin gene products interact in the formation of filaments. To our knowledge. phase variation has not been reported in $\mathrm{Bt}$ and the other possibilities remain to be investigated.

We have compared the deduced $\mathrm{N}$-terminal and $\mathrm{C}$ terminal amino acid sequences of the $f a B$ gene to flagellin amino acid sequences from other bacteria. The flagellins with amino acid sequences similar to that of $\mathrm{Bt}$ flagellin are shown in Fig. 7. Bt flagellin is much like other bacterial flagellins in that the $\mathrm{N}$ - and $\mathrm{C}$-terminal regions are highly conserved whereas the middle region is highly variable (Totten \& Lory, 1990; Joys, 1988). The percentage of identical and similar amino acid residues in Bt flagellin compared to other flagellin proteins has been calculated based on the first 139 and last 80 amino acid residues, the similarity according to Schwartz (Schwartz \& Dayhoff, 1979) with a cut-off index $\geqslant 0.5$. The percentages of identical (similar) amino acid residues are as follows: E. coli $42.9 \%(58.4 \%)$, B. subtilis $42.5 \%$ $(62 \cdot 1 \%)$, P. aeruginosa $40 \cdot 6 \%(55 \cdot 7 \%)$. Percentages of identical amino acid residues have also been calculated for Borrelia burgdorferi, 33\%, Campylobacter coli, 32\% and Caulobacter crescentus, 19\% (Wallich et al., 1990; Fischer \& Nachamkin, 1991). The amino acid composition of $\mathrm{Bt}$ flagellin is similar to other flagellin 
proteins, which always lack cystein and frequently lack tyrosine, tryptophan and histidine (Joys, 1988; Totten \& Lory, 1990).

The flanking $5^{\prime}$ ends of $f a A$ and $f l a B$ are quite different; only about 30 bases upstream from the start site are homologous in the two genes. In both genes, conventional vegetative promoters were found (Fig. 3). Two putative $f l a B$ promoters start at positions 248 and 284 respectively and a putative $f l a A$ promoter starts at position 319 (Fig. 3). Synthesis of bacterial flagella is under numerous levels of control (Helmann, 1991); transcription of flagellin genes requires gene products higher in a regulatory cascade including components such as $\sigma$ factors. In the $f l a A$ gene, we found the sequence GGCAGCGTAGTAGC (nt 23 to 36) containing the conserved sequence $\mathrm{GGN}_{10} \mathrm{GC}$ (Fig. 3) similar to the promoter sequences of flagellin genes in Caulobacter crescentus recognized by $\sigma^{54}$-like factors (Ninfa et al., 1989). Similar sequences are found upstream of the E. coli flagellin gene but do not seem to be used as promoters (Mirel \& Chamberlin, 1989). By computer analysis, we also searched for $\mathrm{P}_{28}$ promoter sequences

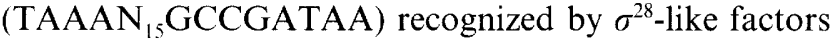
(Helmann, 1991) but found none. Such promoters are used in flagellin genes in both B. subtilis and E. coli (Mirel \& Chamberlin, 1989). The identification of the $\mathrm{Bt}$ flagellin promoters remains to be made but coupled with our findings that flagellin expression is not completely abolished by glucose (Fig. 5) and that both genes are expressed during exponential growth in complex medium (Fig. 4), these presumptive promoters suggest that control of Bt flagellin expression may differ from the current paradigm for flagellar gene regulation (Helmann, 1991).

The finding of the $355 \mathrm{bp}$ direct repeats in the $\mathrm{AaB}$ gene is unprecedented in that the repeats are identical and constitute part of the coding sequence (only 77 bases do not code for either the $\mathrm{N}$-terminal or C-terminal part of the flagellin). Similar phenomena have been found in three porcine Mycoplasma and Mycoplasma pneumoniae genomes, namely similar length repeats that intrude into the coding sequence of a gene, in this case the main adhesin gene (Wenzel \& Herrmann, 1988; Su et al., 1988; Colman et al., 1990). However, in the Mycoplasma example the repeat sequence is not found twice in the same gene. The function of these long repeats in Mycoplasma is not fully understood although according to Colman et al. (1990) these regions on the chromosome are subject to recombination events. The sequence repeats in the $f a B$ gene do show a short sequence of homology (29 identical bases out of $43,68 \%$ ) to one Mycoplasma pneumoniae repeat, but the significance of this is not obvious. Repeats are also found in Vibrio cholerae flanking the cholera toxin gene. In $V$. cholerae, the repeat regions seem to facilitate amplification of the cholera toxin gene (Goldberg \& Mekalanos, 1986). A similar mechanism could explain the high copy number of the flagellin contained sequence in subsp. kurstaki. Another explanation of the high copy number could be that DNA sequences containing the two repeats constitute a mobile element. This is unlikely, however, because no target duplication is found flanking the long repeats and no complete ORF is found within the repeat. The question is then if the repeats confer some selective advantage to Bt. We have found a high copy number in independently isolated kurstaki strains and consequently conclude that the high copy number confers some survival value. According to our results, the high copy number is not due to location of the gene on a high copy number plasmid, since no hybridization to plasmid bands is obtained (results not shown). It is very tempting to speculate that the usefulness of subsp. kurstaki as an insecticide is due at least in part to the multiple copies of the flagellin gene.

The results from the Southern blot experiments (Table 1) show that the $f a B$ gene could be used as a probe to find flagellin genes in several other $\mathrm{Bt}$ subspecies. In this way, the specific variable parts could be identified and compared; oligonucleotides specific for the different serotypes could be designed to facilitate an easy identification of Bt serotypes.

We thank Steven Muir for careful reading of the manuscript. This work was supported by Carl Tryggers Stiftelse för Vetenskaplig forskning (R.L.) and the Swedish Research Council for Engineering Sciences (A. E.).

\section{References}

Bergman, K., Nulty, E. \& Su, L. (1991). Mutations in the two flagellin genes of Rhizobium meliloti. Journal of Bacteriology 173. 3716-3723.

Colman, S. D., Hu, P. C. \& Bott, K. F. (1990). Prevalence of novel repeat sequences in and around the $P l$ operon in the genome of Mycoplasma pneumoniae. Gene 87, 91-96.

Cooper, D. J., Zhang, Q. Y., Arellando, A. \& Pinnock. D. E. (1990). The effect of Bacillus thuringiensis var. tolworthi on Lucilia cuprina larval tissue - an ultrastructural study. Vth International Colloquium on Invertebrate Pathology and Microbial Comtrol, 357.

Dalhammar, G. \& Steiner, H. (1984). Characterization of inhibitor A. a protease from Bacillus thuringiensis which degrades attacins and cecropins, two classes of antibacterial proteins in insects. Europe'm Journal of Biochemistry 139, 247-252.

Edlund, T., Sidén, I. \& Boman, H. G. (1976). Evidence for two immune inhibitors from Bacillus thuringiensis interfering with the humoral defence system of saturniid pupae. Infection and Imminnity. 14, 934-941.

Edman, P. \& BegG, G. (1967). A protein sequenator. European Journal of Biochemistry 1, 80-91.

FAUST, R. M. (1977). Toxins of Bacillus thuringiensis: mode of action. In Biological Regulation of Vectors. The Saprophytic and Aerohic Bacteria and Fungi, pp. 31-48. Edited by J. D. Briggs. DHEW publication no. (NHI) 77-1180, Washington. DC.

Ferre, J., Real, M. D., Van Rie, J., Jansens, S. \& Pefleroen, M. (1991). Resistance to the Bacillus thuringiensis bioinsecticide in at field population of Plutella xylostella is due to a change in a midgut 
membrane receptor. Proceedings of the Natational Academy of Sciences of the United States of America 88, 5119-5123.

Fischer, S. H. \& NACHAMkin, I. (1991). Common and variable domains of the flagellin gene, flaA, in Campylobacter jejuni. Molecular Microbiology 5, 1151-1158.

George, D. G., Barker, W. C. \& Hunt, L. T. (1986). The protein identification resource (PIR). Nucleic Acids Research 14, 11-15.

Goding, J. W. (1983). Monoclonal Antibodies: Principles and Practice. London: Academic Press.

Goldberg, I. \& Mékalanos, J. J. (1986). Effect of a recA mutation on cholera toxin gene amplification and deletion events. Journal of Bacteriology 165, 723-731.

Guerry, P., Alm, R. A., Power, M. E., Logan, S. M. \& Trust, T. J. (1991). Role of two flagellin genes in Campylobacter motility. Journal of Bacteriology 173, 4757-4764.

Heierson, A., Sidén, I., Kivaisi, A. \& Boman, H. G. (1986). Bacteriophage-resistant mutants of Bacillus thuringiensis with decreased virulence in pupae of Hyalophora cecropia. Journal of Bacteriology 167, 18-24.

HELMANN, J. D. (1991). Alternative sigma factors and the regulation of flagellar gene expression. Molecular Microbiology 5, 2875-2882.

Henner, D. J., Yang, M., Chen, E., Hellmiss, R., Rodriguez, H. \& Low, M. G. (1988). Sequence of the Bacillus thuringiensis phosphatidylinositol specific phospholipase C. Nucleic Acids Research 16, 10383.

HöfTE, H. \& Whiteley, H. R. (1989). Insecticidal crystal proteins of Bacillus thuringiensis. Microbiological Reviews 53, 242-255.

Joys, T. M. (1988). The flagellar filament protein. Canadian Journal of Microbiology 34, 452-458.

Karamanlidou, G., Lambropoulos, A. F., Koliais, S. I., Manousis, T., Ellar, D. \& Kastritsis, C. (1991). Toxicity of Bacillus thuringiensis to laboratory populations of the olive fruit fly (Dacus oleae). Applied and Environmental Microbiology 57, 2277-2282.

Kelly-Wintenberg, K., Anderson, T. \& Montie, T. C. (1990). Phosphorylated tyrosine in the flagellum filament protein of Pseudomonas aeruginosa. Journal of Bacteriology 172, 5135-5139.

Klemenz, R., Hultmark, D. \& Gehring, W. J. (1985). Selective translation of heat shock mRNA in Drosophila melanogaster depends on sequence information in the leader. EMBO Journal 4, 2053-2060.

Kostrzynska, M., Betts, J. D., Austin, J. W. \& Trust, T. J. (1991). Identification, characterization, and spatial localization of two flagellin species in Helicobacter pylori flagella. Journal of Bacteriology 173, 937-946.

KRIEG, A. (1986). Bacillus thuringiensis, ein mikrobielles Insektizid. Berlin \& Hamburg: Paul Payer Scientific Publishers.

Kuwajima, G., Asaka, J. L., Fujiwara, T., Node, K. \& Kondo, E. (1986). Nucleotide sequence of the hag gene encoding flagellin of Escherichia coli. Journal of Bacteriology 168, 1479-1483.

Landén, R., Heierson, A. \& Boman, H. G. (1981). A phage for generalized transduction in Bacillus thuringiensis and mapping of four genes for antibiotic resistance. Journal of General Microbiology 123, 49-59.

Li, R. S., Jarret, P. \& Burges, H. D. (1987). Importance of spores, crystals, and $\delta$-endotoxins in the pathogenicity of different varieties of Bacillus thuringiensis in Galleria mellonella and Pieris brassicae. Journal of Invertebrate Pathology 50, 277-284.

Logan, S. M., Trust, T. J. \& Guerry, P. (1989). Evidence for posttranslational modification and gene duplication of Campylobacter flagellin. Journal of Bacteriology 171, 3031-3038.

Lövgren, A., Zhang, M., Engström, Å., Dalhammar, G. \& LandÉn, R. (1990). Molecular characterization of immune inhibitor A, a secreted virulence protease from Bacillus thuringiensis. Molecular Microbiology 4, 2137-2146.

MCGaughey, W. H. (1985). Insect resistance to the biological insecticide Bacillus thuringiensis. Science 229, 193-195.

MCSWEEGAN, E. \& WALKER, R. I. (1986). Identification and characterization of two Campylobacter jejuni adhesins for cellular and mucos substrates. Infection and Immunity 53, 141-148.
Maniatis, T., Fritsch, E. F. \& Sambrook, J. (1982). Molecular Cloning: A Laboratory Manual. Cold Spring Harbor, NY: Cold Spring Harbor Laboratory.

Mirel, D. B. \& Chamberlin, M. J. (1989). The Bacillus subtilis flagellin gene ( $h a g$ ) is transcribed by the $\sigma^{28}$ form of RNA polymerase. Journal of Bacteriology 171, 3095-3101.

Ninfa, A. J., Mullin, D. A., Ramakrishnan, G. \& Newton, A (1989). Escherichia coli $\sigma^{54}$ RNA polymerase recognizes Caulobacter crecentus $f b G$ and flaN flagellar gene promoters in vitro. Journal of Bacteriology 171, 383-391.

Oiler, L., Kocka, F., Smith, R. W. \& Koffeler, H. (1971). The presence of flagellin A and B in the flagellum of Bacillus pumilus 101. Bacteriological Proceedings, 27.

Ordal, G. W., NetTleton, D. O. \& Hoch, J. A. (1983). Genetics of Bacillus subtilis chemotaxis: isolation and mapping of mutations and cloning of chemotaxis genes. Journal of Bacteriology 154, $1088-1097$.

Rasmuson, T. \& Boman, H. G. (1977). The assay and the specificity problem in insect immunity. In Developmental Immunobiology. p. 83-90. Edited by J. B. Solomon \& J. D. Horton. Amsterdam: Elsevier/North-Holland Biomedical Press.

ReN, G. X., LI, K., YANG, M. \& YI, X. (1975). The classification of the strains of Bacillus thuringiensis group. Acta Microbiologica Sinica 15. 292-301.

RiCHARDSON, K. (1991). Roles of motility and flagellar structure in pathogenicity of Vibrio cholerae: analysis of motility mutants in three animal models. Infection and Immunity 59, 2727-2736.

Schnepf, H. E., Wong, H. C. \& Whiteley, H. R. (1985). The amino acid sequence of a crystal protein from Bacillus thuringiensis deduced from the DNA base sequence. Journal of Biological Chemistry $\mathbf{2 6 0}$. 6264-6272.

Schwartz, R. M. \& Dayhoff, M. O. (1979). Atlas of Protein Sequence and Structure, pp. 353-358. Silver Springs, MD: National Biomedical Research Foundation.

Sebesta, K. \& HorSKa, K. (1970). Mechanism of inhibition of DNAdependent RNA polymerase by exotoxin of Bacillus thuringiensis Biochimica et Biophysica Acta 209, 357-367.

SHOREY, H. H. \& HALE, R. L. (1965). Mass rearing of the larvae of nine noctuid species on a simple artificial medium. Journal of Economic Entomology 58, 522-524.

Sidén, I., Dalhammar, G., Telander, B., Boman, H. G. \& SOMMERVILLE, H. (1979). Virulence factors in Bacillus thuringiensis: purification and properties of a protein inhibitor of immunity in insects. Journal of General Microbiology 114, 45-52.

Smith, R. A. \& Couche, G. A. (1991). The phylloplane as a source of Bacillus thuringiensis variants. Applied and Environmental Mi(robiology 57, 311-315.

Somerville, H. J. \& Pockett, H. V. (1975). An insect toxin from spores of Bacillus thuringiensis and Bacillus cereus. Joumal of General Microbiology 87, 359-369.

Su, C.-J., Chavoya, A. \& Basemna, J. B. (1988). Regions of Mycoplasma pneumoniae cytadhesin PI structural gene exist as multiple copies. Infection and Immunity 56, 3157-3161.

Szekely, E. \& Simon, M. (1983). DNA sequence adjacent to flagellar genes and evolution of flagellar-phase variation. Journal of Bacteriology 155, 7481 .

ThORN, C. B. (1978). Transduction in Bacillus thuringiensis. Applied and Environmental Microbiology 35, 1109-1115.

TOTTEN, P. A. \& LORY, S. L. (1990). Characterization of the type a flagellin gene from Pseudomonas aeruginosa PAK. Journal of bacteriology 172, 7188-7199.

Van Rie, J., MCGaughey, W. H., Johnson, D. E., Barnett, B. D. \& Van MellaerT, H. (1990). Mechanism of insect resistance to the microbial insecticide Bacillus thuringiensis. Science 247, 72-74.

Wallich, R., Moter, S. E., Simon, M. M., Ebnet, K., Heiberger, A \& KRAMER, M. D. (1990). The Borrelia burgdorferi flagellumassociated 41-kilodalton antigen (flagellin): molecular cloning, expression and amplification of the gene. Infection and Immunity $\mathbf{5 8}$ 1711-1719.

Wenzel, R. \& HeRrmanN, R. (1988). Repetitive DNA sequences in Mycoplasma pneumoniae. Nucleic Acids Research 16, 8337-8350. 